\title{
Model Pembelajaran Value Clarification Technique untuk Meningkatkan Kemampuan Berpikir Kritis dan Keterampilan Sosial Siswa
}

\author{
Ardian Maulana ${ }^{1}$, Ibrahim Bafadal ${ }^{2}$, Sri Untari ${ }^{3}$ \\ ${ }^{1}$ Pendidikan Dasar-Universitas Negeri Malang \\ ${ }^{2}$ Administrasi Perkantoran-Universitas Negeri Malang \\ ${ }^{3}$ Pendidikan Kewarganegaraan-Universitas Negeri Malang
}

\begin{tabular}{l}
\hline \hline INFO ARTIKEL \\
\hline Riwayat Artikel: \\
Diterima: 11-04-2019 \\
Disetujui: 24-06-2019 \\
\hline
\end{tabular}

Kata kunci:

critical thinking skills; social skills;

learning model value clarification technique;

kemampuan berpikir kritis;

keterampilan sosial;

model pembelajaran value

clarification technique

\begin{abstract}
This study aims to describe the application of Value Clarification Technique learning model to improve critical thinking ability and students's social skill on the subject content of Pancasila and Civic Education. This study is classroom action research. The subject of the research is fifth clas students of SDN Jember Kidul 02 with total of 55 students. This study is conducted through 2 cycles with three times of learning in each cycle. This study results a percentage of students' critical thinking ability completeness has reached $63 \%$ with average 73,82 in cycle I and has begun to increase $81 \%$ with average 84.36 in cycle II. The percentage of students' social skill has reached $74.37 \%$ in cycle I and increased to be $86,95 \%$ in cycle II.
\end{abstract}

ABSTRAK

\begin{abstract}
Abstrak: Penelitian ini bertujuan mendeskripsikan penerapan model pembelajaran value clarification technique untuk meningkatkan kemampuan berpikir kritis dan keterampilan sosial siswa pada muatan Pendidikan Pancasila dan Kewarganegaraan. Penelitian ini merupakan penelitian tindakan kelas. Subjek penelitian siswa kelas V SDN Jember Kidul 02 yang berjumlah 55 siswa. Penelitian dilakukan dua siklus dengan tiga kali pembelajaran pada setiap siklus. Hasil penelitian menunjukkan persentase ketuntasan kemampuan berpikir kritis siswa mencapai 63\% dengan rata-rata nilai sebesar 73,82 untuk siklus I dan meningkat menjadi $81 \%$ dengan rata-rata nilai 84,36 pada siklus II. Persentase keterampilan sosial siswa mencapai $74,37 \%$ untuk siklus I dan meningkat menjadi $86,95 \%$ pada siklus II.
\end{abstract}

\author{
Alamat Korespondensi: \\ Ardian Maulana \\ Pendidikan Dasar \\ Universitas Negeri Malang \\ Jalan Semarang 5 Malang \\ E-mail: ardianmaulana4049@gmail.com
}

Salah satu muatan pembelajaran dalam kurikulum 2013 adalah Pendidikan Pancasila dan Kewarganegaraan yang bertujuan untuk menanamkan nilai-nilai luhur, moral serta norma berdasarkan budaya bangsa Indonesia kepada siswa. Menurut Levine \& Kawashima (2015), pendidikan kewarganegaraan bukan hanya mengajarkan konten atau keterampilan yang berkaitan dengan kewarganegaraan, tetapi juga berbagai konten akademik dan keterampilan anak- sosial. Keterampilan sosial merupakan perilaku yang dipelajari dan diterima secara sosial untuk memungkinkan seseorang dapat berinteraksi dengan orang lain (Vaz, dkk., 2013). Keterampilan sosial siswa dapat dikembangkan melalui proses pembelajaran yang terencana dengan baik, konten yang relevan serta keaktifan siswa dalam kegiatan pembelajaran (Metzger, 2005).

Materi Pendidikan Pancasila dan Kewarganegaraan haruslah menjadi perhatian penting bagi guru dalam melaksanakan pembelajaran dalam kurikulum 2013. Pembelajaran Kewarganegaraan bukan hanya tentang mengajar anak secara akademis serta bagaimana mereka menjadi patuh, melainkan bertujuan untuk membantu mereka dalam memahami peran mereka di lingkungan masyarakat (Hardee, 2009). Selain itu, pembelajaran PPKn di sekolah dasar bertujuan untuk membentuk siswa menjadi berkarakter, berpikir kritis, dan bertindak demokratis (Susanto, 2013). Kemampuan berpikir kritis sangat dibutuhkan saat ini karena teknologi informasi sudah menjadi bagian terpenting dari siswa. Segala bentuk informasi baik positif maupun negatif bisa didapatkan siswa dengan mudah, Maka dari itu, kemampuan berpikir kritis dibutuhkan agar mereka bisa menganalisis segala bentuk informasi yang baik bagi dirinya. Kemampuan berpikir kritis berkaitan dengan kemampuan menyelesaikan masalah, memutuskan, serta menganalisisnya melalui sebuah proses terarah dan jelas (Johnson, 2012). Kemampuan berpikir kritis yang dimiliki siswa dapat dikembangkan melalui pembelajaran di dalam kelas. Kemampuan berpikir kritis yang dipelajari siswa di dalam kelas tersebut nantinya akan berdampak pada pembelajaran di masa depan untuk siswa (Murawski, 2014). 
Proses pembelajaran di kelas V SDN Jember Kidul 02 belum berjalan dengan maksimal sehingga menyebabkan kemampuan berpikir kritis siswa pada materi PPKn masih rendah. Temuan-temuan yang menguatkan permasalahan tersebut berdasarkan hasil observasi dan wawancara dengan guru kelas V sebagai berikut. Pertama, siswa terlihat pasif dalam proses pembelajaran. Kedua, hanya sebagian siswa saja yang berani untuk mengajukan pertanyaan. Ketiga, belum terlihat siswa yang memberikan tanggapan kritis terkait dengan materi yang diajarkan. Keempat, siswa masih belum bisa memecahkan permasalahan yang diberikan guru. Kelima, siswa belum bisa membuat kesimpulan dari berbagai pernyataan yang disampaikan guru. Keenam, proses pembelajaran yang dilakukan kurang memicu kemampuan siswa untuk mampu berpikir secara kritis dalam menanggapi persoalan.

Selain terdapat permasalahan dalam aspek kemampuan berpikir kritis, data juga menunjukkan keterampilan sosial siswa pada materi PPKn masih rendah. Keterampilan sosial siswa yang rendah dibuktikan dengan temuan-temuan sebagai berikut. Pertama, pembelajaran yang dilakukan belum melibatkan siswa secara aktif. Kedua, kegiatan berkelompok dalam proses pembelajaran belum dilakukan, sehingga siswa kurang dapat berinteraksi melakukan kerjasama dengan teman sekelas dalam proses pembelajaran. Ketiga, ketika guru memberikan tugas masih terdapat siswa yang bergurau sehingga tugas yang diberikan guru tidak selesai tepat waktu, hal tersebut menandakan siswa belum memiliki tanggung jawab yang baik. Keempat, siswa masih belum berani menyampaikan pendapatnya selama proses pembelajaran, hal tersebut menandakan siswa belum memiliki ketegasan yang baik. Kelima, saat siswa bertanya atau menyampaikan pendapat, masih terlihat siswa lain yang berbicara sendiri. Hal tersebut menandakan siswa belum memiliki sikap kontrol diri dan empati yang baik.

Sesuai dengan temuan yang didapat, maka dapat disimpulkan kegiatan pembelajaran yang dilakukan belum memberikan hasil yang maksimal pada kemampuan berpikir kritis serta keterampilan sosial siswa pada materi PPKn. Perlu adanya perbaikan dalam proses pembelajaran dengan menerapkan model pembelajaran Value Clarification Technique sehingga permasalahan dalam kelas dapat teratasi. Klarifikasi nilai yang dilakukan dalam model pembelajaran Value Clarification Technique didasarkan pada gagasan nilai, dimana siswa didorong untuk mengadopsi nilai-nilai mereka sendiri asalkan itu bermakna bagi mereka (Brady, 2011).

Model klarifikasi nilai tidak memberitahu seseorang tentang nilai yang seharusnya dijalani, melainkan menyediakan sarana dalam menemukan nilai-nilai yang harus mereka jalani (Rai, 2014). Dengan penggunaan model Value Clarification Technique dalam proses pembelajaran, diharapkan dapat meningkatkan kesadaran diri siswa terhadap nilai yang terkandung dalam setiap pembelajaran (Oliha \& Audu, 2015). Melalui pendidikan nilai siswa juga dipersiapkan untuk menjadi individu yang mandiri serta mampu menghadapi masalah dan menemukan solusinya (Fahyuni \& Bandono, 2017). Kemampuan siswa dalam menemukan solusi dari permasalahan yang dihadapi tersebut merupakan bagian dari kemampuan berpikir kritis.

\section{METODE}

Penelitian ini merupakan Penelitian Tindakan Kelas. Penelitian dilakukan dengan berkolaborasi dengan guru kelas yang mengalami permasalah di kelasnya. Untuk mengatasi permasalahan yang ada di kelas, peneliti bertindak sebagai guru yang melaksanakan proses pembelajaran. Pelaksanaan siklus terdiri dari tahap perencanaan (plan), pelaksanaan dan observasi (act \& observer) serta refleksi (reflect). SDN Jember Kidul 02 yang terletak di Kelurahan Jember Kidul, Kecamatan Kaliwates, Kabupaten Jember merupakan lokasi dilakukannya penelitian dengan subjek siswa kelas V yang berjumlah 55. Peneliti sebagai guru yang melaksanakan penelitian merupakan instrumen utama dalam penelitian ini, sedangkan instrumen pendukung lainnya berupa lembar observasi untuk keterlaksanaan pembelajaran, lembar observasi untuk keterampilan sosial, soal tes uraian untuk mengetahui kemampuan berpikir kritis siswa serta pedoman wawancara. Observasi, wawancara, dokumentasi, dan tes merupakan teknik yang digunakan untuk mengumpulkan data.

Kriteria keberhasilan tindakan untuk keterlaksanaan pembelajaran dengan menerapkan model pembelajaran Value Clarification Technique adalah sebesar $80 \%$ dengan kriteria baik. Hasil nilai persentase rata-rata observasi pada setiap pembelajaran yang dilakukan untuk mengetahui keterlaksanaan pembelajaran dengan menerapkan model pembelajaran Value Clarification Technique dianalisis dengan kriteria keterlaksanaan pembelajaran yang meliputi sangat kurang $(<20 \%)$, kurang baik $(21-40 \%)$, cukup baik $(41-60 \%)$, baik $(61-80 \%)$, sangat baik $(81-100 \%)$. Kriteria keberhasilan tindakan untuk kemampuan berpikir kritis siswa adalah apabila nilai rata-rata kelas minimal sebesar 75 dengan kriteria tinggi serta $75 \%$ dari jumlah siswa telah memperoleh nilai $>74$ dangan kriteria tinggi dan sangat tinggi. Kriteria kemampuan berpikir kritis yang digunakan, meliputi kriteria sangat rendah dengan nilai (<40), rendah (41_59), sedang (60 — 74), tinggi (75-90), sangat tinggi (90-100). Kriteria keberhasilan tindakan untuk keterampilan sosial siswa adalah apabila persentase nilai rata-rata dari aspek keterampilan sosial siswa yang diamati sudah mencapai minimal 80\% dengan kriteria baik. Hasil observasi keterampilan sosial siswa dianalisis dengan kriteria yang meliputi sangat kurang (<20\%), kurang (21—40\%), cukup (41—60\%), baik (61—80\%), serta sangat baik $(81-100 \%)$. 


\section{HASIL}

Pelaksanaan penelitian dilakukan selama dua siklus dengan tiga kali pembelajaran pada setiap siklus yang dilakukan. Tahap perencanaan, pelaksanaan tindakan, beserta observasi, dan refleksi dilakukan pada setiap siklus. Tahapan perencanaan dilakukan untuk mempersiapkan segala bentuk sarana pendukung serta instrumen yang digunakan untuk mengumpulkan data pada saat melaksanakan tindakan.

Tahap pelaksanaan tindakan dilakukan dengan menerapkan model pembelajaran Value Clarification Technique pada materi PPKn yang terdiri dari tahap kebebasan/memilih, menghargai dan berbuat. Proses pembelajaran pada siklus I dimulai dengan kegiatan awal untuk mengetahui kemampuan yang dimiliki siswa sebelum pembelajaran serta menyiapkan siswa untuk menjalankan proses pembelajaran yang hendak dilakukan. Pada kegiatan inti, siswa sudah diorientasikan pada pelaksanaan langkah-langkah model pembelajaran Value Clarification Technique. Kegiatan pembelajaran dilakukan secara berkelompok dengan anggota 5-6 siswa pada setiap kelompok.

Tahap pertama dari pelaksanaan model pembelajaran Value Clarification Technique adalah kebebasan/memilih. Siswa diorientasikan pada masalah kontekstual yang hendak diklarifikasi menggunakan gambar. Siswa diminta untuk menentukan atau memilih setelah melakukan pertimbangan mengenai gambar yang ditampilkan apakah sesuai atau tidak dengan nilai yang hendak dibangun dalam proses pembelajaran.

Selama siswa melakukan aktivitas diskusi kelompok, guru menghampiri dan memantau sejauh mana siswa bekerja. Siswa tidak mendapat tekanan dari guru selama proses memilih. Hal tersebut dilakukan dengan harapan siswa akan senang dan bangga dengan hasil pilihan kelompok, sehingga mereka akan mau dan percaya diri pada saat mempresentasikannya. Setelah kegiatan berdiskusi selesai, setiap kelompok diminta untuk menyampaikan hasil diskusinya serta kelompok lain diminta menanggapi. Kegiatan tersebut merupakan bagian dari tahapan kedua dari penerapan model pembelajaran Value Clarification Technique yaitu tahapan menghargai.

Tahap ketiga dari penerapan model Value Clarification Technique yaitu berbuat. Siswa melakukan kegiatan diskusi secara klasikal untuk menemukan kesepakatan mengenai nilai-nilai baik yang harus dimiliki siswa. Melalui kegiatan tesebut, siswa juga menyimpulkan materi yang telah dipelajari secara bersama-sama. Selanjutnya, siswa diarahkan untuk mau menerapkan nilai baik yang sudah menjadi kesepakatan bersama dalam kehidupan sehari-hari agar memberikan kontribusi yang baik dalam kehidupan bermasyarakat.

Dalam proses pembelajaran yang dilakukan, peneliti dibantu oleh empat orang observer yang bertugas untuk mengobservasi keterlaksanaan pembelajaran menggunakan model Value Clarification Technique dan keterampilan sosial siswa. Pada akhir siklus dilaksanakan tes dengan soal uraian yang memuat indikator kemampuan berpikir kritis. Tahapan penelitian diakhiri dengan refleksi antara peneliti dengan observer untuk mengetahui ketercapaian keterlaksanaan pembelajaran yang telah dilakukan, permasalahan yang muncul dalam pembelajaran, serta solusi sebagai perbaikan pada siklus berikutnya. Berikut adalah tabel ringkasan dari kriteria keberhasilan tindakan untuk siklus I.

Tabel 1. Ketercapaian Hasil Tindakan Siklus I

\begin{tabular}{llll}
\hline \multicolumn{1}{c}{ Indikator } & Kriteria Keberhasilan & Hasil Siklus II & Keterangan \\
\hline Keterlaksanaan pembelajaran oleh guru & $80 \%$ & $93,14 \%$ & Berhasil \\
\hline Keterlaksanaan pembelajaran oleh siswa & $80 \%$ & $87,91 \%$ & Berhasil \\
\hline Observasi keterampilan sosial siswa & $80 \%$ & $74,37 \%$ & Belum berhasil \\
\hline Ketuntasan klasikal kemampuan berpikir kritis & $75 \%$ & $63 \%$ & Belum berhasil \\
\hline Nilai rata-rata kelas kemampuan berpikir kritis & 75 & 73,82 & Belum berhasil \\
\hline
\end{tabular}

Berdasarkan data-data yang diuraikan menunjukkan bahwa hasil keterlaksanaan pembelajaran oleh guru dan siswa sudah melampaui yang ditargetkan sedangkan kemampuan berpikir kritis dan keterampilan sosial siswa belum mencapai kriteria keberhasilan tindakan yang ditargetkan. Berdasarkan hasil refleksi antara peneliti dan observer maka diputuskan untuk melaksanakan tindakan pada siklus berikutnya dengan tujuan memperbaiki proses pembelajaran siklus I sehingga kemampuan berpikir kritis dan keterampilan sosial siswa dapat mancapai kriteria keberhasilan tindakan yang sudah ditargetkan.

Materi yang digunakan untuk siklus II sama seperti siklus I namun ada penambahan materi pada pertemuan ketiga. Perbaikan yang dilakukan pada siklus II diantaranya (a) penambahan jumlah kelompok dalam kelas sehingga tiap kelompok beranggotakan 4-5 siswa, (b) guru memberikan perhatian lebih kepada siswa yang pasif dan menunjukkan perilaku yang kurang baik selama proses pembelajaran siklus I, (c) penambahan waktu pelaksanaan pembelajaran menggunakan model Value Clarification Technique (d) penggunaan media video dan kliping untuk mengorientasi siswa terhadapat persoalan yang hendak diklarifikasi (e) pemberian aturan yang lebih ketat serta pembelajaran dibuat dengan kompetisi dimana kelompok yang paling banyak memperoleh point akan mendapatkan reward.

Berdasarkan hasil observasi selama tindakan, diketahui keterlaksanaan pembelajaran menggunakan model Value Clarification Technique untuk siklus II sudah berlangsung lebih baik daripada siklus sebelumnya. Kemampuan berpikir kritis dan keterampilan sosial siswa juga mengalami peningkatan daripada siklus I. Berikut adalah tabel ringkasan dari kriteria keberhasilan tindakan untuk siklus II. 
Tabel 2. Ketercapaian Hasil Tindakan Siklus II

\begin{tabular}{llll}
\hline \multicolumn{1}{c}{ Indikator } & Kriteria Keberhasilan & Hasil Siklus II & Keterangan \\
\hline Keterlaksanaan pembelajaran oleh guru & $80 \%$ & $96,41 \%$ & Berhasil \\
\hline Keterlaksanaan pembelajaran oleh siswa & $80 \%$ & $93,79 \%$ & Berhasil \\
\hline Observasi keterampilan sosial siswa & $80 \%$ & $86,95 \%$ & Berhasil \\
\hline Ketuntasan klasikal kemampuan berpikir kritis & $75 \%$ & $81 \%$ & Berhasil \\
\hline Nilai rata-rata kelas kemampuan berpikir kritis & 75 & 84,36 & Berhasil \\
\hline
\end{tabular}

Berdasarkan analisis hasil refleksi siklus II dapat disimpulkan bahwa semua indikator yang meliputi keterlaksanaan pembelajaran oleh guru dan siswa, kemampuan berpikir kritis, serta keterampilan sosial siswa telah melampaui kriteria keberhasilan dalam penelitian yang sudah ditargetkan. Dengan hasil yang sudah didapatkan dan setiap indikator telah mengalami peningkatan jika dibandingkan pada siklus I sehingga tidak perlu diberikan tindakan selanjutnya.

\section{PEMBAHASAN}

\section{Penerapan Model Pembelajaran Value Clarification Technique dalam Muatan PPKn}

Penerapan proses pembelajaran menggunakan model Value Clarification Technique dalam pembelajaran materi PPKn diawali dengan membagi siswa menjadi beberapa kelompok. Siswa dikelompokkan secara heterogen dengan anggota kelompok yang berbeda-beda pada setiap pembelajaran yang dilakukan. Dalam proses pembelajaran materi PPKn menggunakan model Value Clarification Technique terdapat tiga nilai yang di bangun dalam proses pembelajaran, yaitu nilai Bhinneka Tunggal Ika, nilai persatuan dan kesatuan, serta nilai toleransi dan tenggang rasa dalam keberagaman sosial budaya di masyarakat.

Melalui kegiatan kelompok, siswa melakukan kegiatan bertukar pikiran dalam proses diskusi sehingga kemampuan berpikir kritis siswa dapat dikembangkan melalui proses tersebut. Sesuai yang disampaikan Etkina \& Planinsic (2015), untuk mengembangkan kemampuan berpikir kritis siswa dibutuhkan aktivitas sosial antar siswa dalam kegiatan kelompok sehingga siswa dapat bertukar pikiran untuk mengembangkan ide yang dimiliki. Selain itu, kegiatan berkelompok menjadikan siswa lebih aktif sehingga dapat mengembangkan keterampilan sosial yang dimiliki siswa. Sesuai dengan pendapat yang disampaikan Rachmadyanti \& Rochani (2017) yang menyatakan bahwa pelibatan siswa secara aktif dalam serangkaian kegiatan pembelajaran menggunakan model Value Clarification Technique dapat mengemabangkan keterampilan sosial yang dimiliki siswa dengan baik.

Tahapan pertama dari pelaksanaan model pembelajaran Value Clarification Technique adalah kebebasan memilih. Siswa memilih dari berbagai alternatif, menganalisis dan mengambil keputusan berkaitan dengan gambar, kliping, dan video sebagai media stimulus untuk menampilkan fenomena yang terjadi di masyarakat untuk nantinya akan diklarifikasi oleh siswa melalui aktivitas diskusi kelompok. Dalam aktivitas diskusi kelompok, siswa diminta untuk mengumpulkan segala bentuk informasi yang relevan sebagai dasar untuk siswa dalam menentukan dan mempertimbangkan pilihannya. Aktivitas siswa tersebut merupakan bagian dari kegiatan yang dapat mengembangkan kemampuan berpikir kritis siswa. Guru bertindak sebagai fasilitator untuk mendampingi siswa dalam aktivitas diskusi kelompok selama proses pembelajaran. Melalui aktivitas kelompok, setiap siswa menunjukkan perilakunya dalam menjalin interaksi dengan anggota kelompoknya. Aktivitas yang dilakukan siswa dalam menjalin interaksi dengan anggota kelompok merupakan bagian dari keterampilan sosial yang dimiliki oleh siswa.

Tahap kedua dari pelaksanaan model pembelajaran Value Clarification Technique adalah menghargai. Siswa diberi kesempatan untuk mengakui pilihannnya di depan umum melalui kegiatan presentasi. Selama melakukan kegiatan presentasi, siswa tidak mendapatkan tekanan dari guru sehingga siswa percaya diri dan bahagia dengan pilihannya. Selama kegiatan presentasi, siswa juga mendapatkan pertanyaan-pertanyaan klarifikasi dari guru. Melalui pertanyaan-pertanyaan tersebut, guru dapat melihat kemampuan berpikir kritis siswa dalam menanggapi serta menjawab pertanyaan yang disampaikan. Selama proses pembelajaran berlangsung dengan menggunakan model Value Clarification Technique, guru dan siswa menjalankan prinsip keterbukaan sehingga tujuan pembelajaran dapat tercapai dengan baik. Keterbukaan antara guru dan siswa diwujudkan melalui serangkaian kegiatan tanya jawab yang dilakukan selama proses pembelajaran. Guru menyampaikan pertanyaanpertanyaan klarifikasi kepada siswa sehingga nantinya siswa dapat menemukan dan memahami mengenai nilai baik yang hendak dicapai dalam proses pembelajaran. Pemberian kesempatan siswa dari kelompok lain untuk memberikan tanggapan, bertujuan untuk mengajarkan siswa tentang bagaimana menghargai serta menerima pendapat dari orang lain sebagai bahan pertimbangan dalam mengambil keputusan. Sesuai yang disampaikan Sanjaya (2014), penggunaan Value Clarification Technique sebagai model pembelajaran bertujuan untuk melatih siswa tentang bagaimana cara menerima, menilai, serta mengambil keputusan mengenai persoalan yang dihadapi dalam kehidupan.

Tahap ketiga dari pelaksanaan model pembelajaran Value Clarification Technique adalah berbuat. Guru melakukan diskusi secara klasikal bersama siswa untuk mengklarifikasi nilai yang akan ditanamkan kepada siswa. Selama kegiatan diskusi terjadi interaksi yang baik antara siswa dengan guru melalui pertanyaan yang disampaikan secara terbuka. Sesuai yang disampaikan Taniredja, dkk. (2015), salah satu prinsip dari penggunaan model Value Clarification Technique dalam proses pembelajaran adalah perlunya keterbukaan antara guru dengan siswa sehingga tujuan dari penggunaan model ini dapat tercapai 
dengan baik. Setelah siswa melakukan kegiatan klarifikasi secara klasikal dan menemukan kesepakatan mengenai nilai-nilai baik mengenai materi yang sudah dipelajari, kemudian guru memberi pengarahan kepada siswa untuk melaksanakan nilai baik tersebut dalam bentuk perilaku di kehidupan bermasyarakat.

Keseluruhan kegiatan pembelajaran yang dilakukan sudah terlaksana dengan sangat baik. Skor pelaksanaan pembelajaran oleh guru sebesar 93,14\% untuk siklus I dan mengalami kenaikan menjadi 96,41\% pada siklus II dengan kriteria yang sama yaitu sangat baik. Untuk pelaksanaan pembelajaran oleh siswa siklus I sebesar $87,91 \%$ dan mengalami peningkatan pada siklus II menjadi 93,79\% dengan kriteria yang sama yaitu sangat baik. Melalui hasil observasi tersebut diketahui bahwa pelaksanaan pembelajaran baik oleh guru maupun siswa berjalan dengan sangat baik.

\section{Peningkatan Kemampuan Berpikir Kritis Siswa}

Terjadi peningkatan kemampuan berpikir kritis siswa setelah penerapan model pembelajaran Value Clarification Technique yang diketahui melalui hasil tes pada akhir setiap siklus dengan soal uraian berjumlah delapan butir. Soal tes kemampuan berpikir kritis disusun berdasarkan indikator dari Ennis (2011) yang meliputi (1) menganalisis argumen, (2) mempertimbangkan sumber, apakah dapat dipercaya atau tidak, (3) membuat kesimpulan (induksi) dan mempertimbangkan hasil, (4) mendefinisikan istilah dan menggunakan kriteria yang sesuai, (5) memberikan pertimbangan dan alasan yang tepat, (6) memproses tujuan untuk situasi yang sesuai.

Berdasarkan analisis yang telah dilakukan setelah penerapan model Value Clarification Technique dalam proses pembelajaran, diketahui bahwa siswa yang memperoleh nilai dengan rentang $(91-100)$ dengan kriteria sangat tinggi sebesar 25\% untuk siklus I, kemudian naik menjadi 38\% pada siklus II. Siswa yang memperoleh nilai dengan rentang (75-90) dengan kriteria tinggi sebesar 38\% untuk siklus I, kemudian naik menjadi $43 \%$ pada siklus II. Siswa yang memperoleh nilai dengan rentang (60-74) dengan kriteria sedang sebesar 23\% untuk siklus I, kemudian turun menjadi 19\%.pada siklus II. Siswa yang memperoleh nilai dengan rentang (40-59) dengan kriteria rendah sebesar $15 \%$ untuk siklus I, kemudian turun menjadi $0 \%$ pada siklus II. Tidak ada siswa yang memperoleh nilai (<40) dengan kriteria sangat rendah untuk siklus I maupun siklus II.

Nilai rata-rata siswa secara klasikal mengalami peningkatan dari siklus I ke siklus II. Nilai rata-rata kemampuan berpikir kritis klasikal pada siklus I sebesar 73,82 dengan kriteria sedang dan terjadi peningkatan menjadi 84,36 dengan kriteria tinggi pada siklus II. Selain itu, terjadi peningkatan ketuntasan siswa secara klasikal. Untuk siklus I persentase jumlah siswa yang memperoleh nilai > 74 dengan kriteria tinggi dan sangat tinggi sebesar 63\%, kemudian pada siklus II mengalami kenaikan yang signifikan menjadi $81 \%$. Berikut disajikan pada tabel 3 peningkatan kemampuan berpikir kritis siswa dari siklus I ke siklus II.

Tabel 3. Peningkatan Kemampuan Berpikir Kritis Siswa Siklus I ke Siklus II

\begin{tabular}{clccc}
\hline No. & Hasil Kemampuan Berpikir Kritis & Siklus I & Siklus II & Peningkatan \\
\hline 1. & Nilai Rata-rata Klasikal & 73,82 & 84,36 & 10,54 \\
\hline 2. & Ketuntasan Klasikal & $63 \%$ & $81 \%$ & $18 \%$ \\
\hline
\end{tabular}

Melalui serangkaian proses pembelajaran yang memberikan pengalaman siswa dalam mengumpulkan informasi, menganalisis, menentukan, dan mengambil keputusan dari permasalahan yang diambil dari fenomena sederhana dengan menggunakan media gambar, video, dan kliping maka kemampuan berpikir siswa dapat ditingkatkan. Sesuai yang disampaikan Etkina \& Planinsic (2015), salah satu hal yang perlu diperhatikan dalam mengembangkan kemampuan berpikir kritis siswa adalah fenomena sederhana untuk diamati oleh siswa sehingga mereka dapat menjelaskan fenomena tersebut dalam kalimat yang sederhana.

Selain itu, dalam proses pembelajaran menggunakan model pembelajaran Value Clarification Technique, siswa diminta untuk mengumpulkan segala bentuk informasi yang relevan sebagai dasar untuk siswa dalam memilih dari berbagai alternatif. Kegiatan siswa dalam mengumpulkan segala bentuk informasi yang relevan merupakan salah satu bentuk dari langkah pemikiran reflektif yang dapat mengembangkan kemampuan berpikir kritis siswa. Sesuai yang disampaikan Iskandar, dkk. (2017), model Value Clarification Technique dapat mengembangkan kemampuan berpikir kritis siswa dikarenakan di dalam proses pembelajaran yang dilakukan mencakup langkah dari pemikiran reflektif .

\section{Peningkatan Keterampilan Sosial Siswa}

Keterampilan sosial siswa mengalami peningkatan setelah penerapan model pembelajaran Value Clarification Technique. Untuk mengetahui peningkatan keterampilan sosial siswa setelah penerapan model pembelajaran Value Clarification Technique maka dilakukan dengan observasi. Aspek keterampilan sosial yang diamati dalam penelitian ini mengacu pada pendapat Gresham, dkk. (2011) yaitu: (1) kerjasama; (2) ketegasan; (3) tanggung jawab; (4) kontrol diri; (5) empati. Berdasarkan analisis yang telah dilakukan setelah penerapan model Value Clarification Technique dalam proses pembelajaran, diketahui skor perolehan aspek kerjasama untuk siklus I sebesar $71,01 \%$ kemudian naik pada siklus II menjadi $85,35 \%$. Skor perolehan aspek ketegasan sebesar 75,03\% untuk siklus I kemudian naik menjadi 88,28\% pada siklus II. Skor perolehan aspek tanggung jawab sebesar 77,24\% untuk siklus I, kemudian naik menjadi 89,05\% pada siklus II. Skor perolehan 
aspek kontrol diri sebesar 73,73\% untuk siklus I, kemudian naik menjadi 85,95\% pada siklus II. Skor perolehan aspek empati sebesar 74,86\% untuk siklus I, kemudian naik menjadi 86,10\% pada siklus II. Perolehan skor rata-rata dari kelima aspek keterampilan sosial siswa secara klasikal sebesar 74,37\% dengan kategori baik untuk siklus I, serta mengalami peningkatan yang signifikan menjadi 86,95\% dengan kategori sangat baik pada siklus II. Berikut disajikan pada tabel 4 peningkatan skor nilai rata-rata dari perolehan kelima aspek keterampilan sosial yang diamati.

Tabel 4. Peningkatan Keterampilan Sosial Siswa Siklus I ke Siklus II

\begin{tabular}{clccc}
\hline No. & Hasil Keterampilan Sosial Siswa & Siklus I & Siklus II & Peningkatan \\
\hline 1. & $\begin{array}{l}\text { Rata-rata Nilai Persentase } \\
\text { Keterampilan Sosial Siswa }\end{array}$ & $74,37 \%$ & $86,95 \%$ & $12,58 \%$ \\
\hline
\end{tabular}

Melalui kegiatan kelompok dalam penerapan model pembelajaran Value Clarification Technique maka siswa dapat menunjukkan sikap saling bekerjasama yang baik dengan anggota kelompoknya. Aspek kerjasama yang muncul selama proses pembelajaran merupakan bagian dari keterampilan sosial yang dimiliki siswa. Sesuai yang disampaikan Nasia, dkk. (2014), penerapan model Value Clarification Technique dapat meningkatkan aspek kerjasama siswa dalam proses pembelajaran melalui aktivitas berkelompok. Selain itu, penggunaan konten masalah kontekstual untuk di klarifikasi selama proses pembelajaran menggunakan model Value Clarification Technique menyebabkan siswa lebih aktif. Keaktifan siswa melalui penggunaan konten masalah kontekstual menyebabkan keterampilan sosial yang dimiliki siswa dapat dikembangkan dengan baik. Sesuai yang disampaikan Parmiti (2018), melalui penggunaan model pembelajaran Value Clarification Technique dengan konten masalah kontekstual memberikan dampak baik terhadap keterampilan sosial siswa.

\section{SIMPULAN}

Melalui hasil refleksi dari dua siklus yang dilaksanakan, maka disimpulkan bahwa penerapan model pembelajaran Value Clarification Technique pada materi PPKn dapat meningkatkan kemampuan berpikir kritis serta keterampilan sosial siswa kelas V SDN Jember Kidul 02. Hasil persentase ketuntasan kemampuan berpikir kritis siswa mencapai $63 \%$ dengan nilai rata-rata klasikal 73,82 yang masuk kriteria sedang untuk siklus I. Kemudian terjadi peningkatan pada persentase ketuntasan menjadi $81 \%$ dengan nilai rata-rata sebesar 84,36 yang masuk kriteria tinggi untuk siklus II. Keterampilan sosial siswa juga mengalami peningkatan setelah penerapan model pembelajaran Value Clarification Technique. Hasil persentase keterampilan sosial siswa untuk siklus I mencapai $74,37 \%$ dengan kriteria baik dan mengalami peningkatan menjadi $86,95 \%$ dengan kriteria sangat baik pada siklus II.

Saran yang dapat diberikan terkait penelitian yang sudah dilakukan sebagai berikut. Pertama penerapan model Value Clarification Technique dalam proses pembelajaran dapat digunakan dalam meningkatkan aspek aspek kemampuan berpikir kritis serta keterampilan sosial siswa, namun harus disesuaikan dengan karakteristik materi yang hendak diajarkan. Kedua, guru harus membangun nuansa kekeluargaan yang akrab dengan siswa, sehingga siswa berani untuk berpendapat atau mempunyai pendapat yang berbeda dengan guru maupun siswa yang lain. Ketiga, penerapan model Value Clarification Technique membutuhkan pengelolaan kelas, baik tempat, waktu, maupun pengelompokan siswa yang baik apabila pembelajaran ingin dibuat secara berkelompok. Keempat, untuk peneliti selanjutnya penggunakan model Value Clarification Technique harus memperhatikan beberapa hal, di antaranya (a) harus menjelaskan langkah-langkah pembelajaran secara terperinci dan jelas hingga siswa dapat menjalankan peranannya dalam pembelajaran dengan baik, (b) penerapan model Value Clarification Technique juga dapat menggunakan media pembelajaran untuk mengorientasi siswa pada masalah yang hendak di klarifikasi, (c) pertanyaan-pertanyaan klarifikasi yang diajukan kepada siswa harus mudah dipahami, (d) upayakan materi yang digunakan pada setiap siklus dikembangkan dengan baik, karena ada kecenderungan siswa merasa jenuh ketika memberikan materi yang sama pada setiap siklus yang dilakukan.

\section{DAFTAR RUJUKAN}

Brady, L. (2011). Teacher Values and Relationship: Factors in Values Education. Australian Journal of Teacher Education, $36(2), 56-66$.

Oliha, J., \& Audu, I. V. (2015). Effectiveness of Value Clarification and Self-Management Techniques in Reducing Dropout Tendency Among Secondary Schools Students In Edo State. European Journal of Educational and Development Psychology, 3(1), 1-13.

Fahyuni, E. F., \& Bandono, A. (2017). The use of Value Clarification Technique-Based- Picture Story Media as an Alternative Media to Value Education in Primary School. Harmonia: Journal of Arts Research and Education, 17(1), 68-74.

Ennis, R. H. (2011). The Nature of Critical Thinking: An Outline of Critical Thinking Dispositions. Sixth International Conference on Thinking at MIT.

Etkina, E., \& Planinsic, G. (2015). Defining and Developing “Critical Thinking” Through Devising and Testing Multiple Explanations of the Same Phenomenon. The Physics Teacher, 53(7), 432-437. 
Gresham, F. M., Elliott, S. N., Vance, M. J., \& Cook, C. R. (2011). Comparability of the Social Skills Rating System to the Social Skills Improvement System: Content and Psychometric Comparisons Across Elementary and Secondary Age Levels.. School Psychology Quarterly, 26(1), 27-44.

Hardee, D. (2010). Passionate Pedagogy: Understanding the Impact of Teachers Values and Beliefs on Citizenship /Character Education for Children of Color. UMI Dissertation Publishing.

Iskandar, D., Rahmawati, D., \& Hamdai, A. R. (2017). The Impact of Application of Value Clarification Technique (VCT) Towards Ecoliteracy and Critical Thinking Skill Student of Social Science In Primary School. Journal of Education and Technology, 1(1), 28-43.

Johnson, E. B. (2012). Contextual Teaching \& Learning Menjadikan Kegiatan Belajar- Mengajar Mengasyikkan dan Bermakna. Bandung: Mizan Media Utama.

Levine, P., \& Kawashima-Ginsberg, K. (2015). Civic Education and Deeper Learning. Deeper Learning Research Series. Jobs For the Future, (February), 1-28.

Metzger, D. (2005). Rethinking Classroom Management. Social Studies and the Young Learner, 17(2), 13-15.

Murawski, L. M. (2014). Critical Thinking In The Classroom and Beyond. Spring, 10(1), 25-30.

Nasia, S., Saneba, B., \& Hasdin. (2014). Meningkatkan Kerjasama Siswa pada Pembelajaran PKN melalui Value Clarification Technique (VCT) di Kelas IV GKLB Sabang. Jurnal Tadulako Online, 2(3), 63-77.

Parmiti, D. P. (2018). The Effect of Value Clarification Technique (VCT) using Contextual Problem Content on Social Attitude and Social Science Learning Achievement of the Elementary School Students. SHS Web of Conferences, 42(6), 1-6.

Rachmadyanti, P. \& Rochani. (2017). Pengembangan Social Skill Siswa Sekolah Dasar melalui Teknik Pembelajaran VCT (Value Clarification Technique. Dwijacendekia Jurnal Riset Pedagogik, 1(2), 70-78.

Rai, D. R. (2014). Comparative Effectiveness of Value Clarification and Role Playing Value Development Models for Selected Values for Primary School Students. IOSR Journal of Humanities and Social Science. 19(1), 28-34.

Sanjaya, W. (2014). Strategi Pembelajaran Berorientasi Standar Proses Pendidikan. Jakarta: Kencana Prenada Media Group. Susanto, A. (2013). Teori Belajar dan Pembelajaran di Sekolah Dasar. Jakarta: Kencana Prenadamedia Group.

Taniredja, T., Faridli, M., \& Harmianto, S. (2015). Model-Model Pembelajaran Inovatif dan Efektif. Bandung: Alfabeta.

Vaz, S., Parsons, R., Passmore, A. E., Andreou, P., \& Falkmer, T. (2013). Internal Consistency, Test-Retest Reliability and Measurement Error of the Self-Report Version of the Social Skills Rating System in a Sample of Australian Adolescents. PloS One, 8(9), 1-8. 